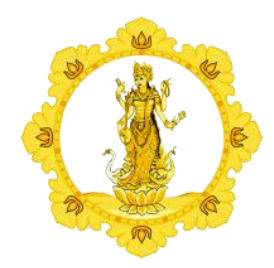

KALANGWAN

JURNAL PENDIDIKAN AGAMA, BAHASA DAN SASTRA

Vol. 11 No. 2 September 2021

\begin{tabular}{l|l|l|} 
p-ISSN : 1979-634X & e-ISSN : 2686-0252 & http://ejournal.indn.ac.id/index.php/Kalangwan \\
\hline
\end{tabular}

\title{
NILAI BUDAYA DALAM CERITA RAKYAT MASYARAKAT MELAYU KABUPATEN MEMPAWAH
}

\author{
Oleh : \\ Sakillah $^{1)}$, Fitri $^{2)}$, Zulfahita $^{3)}$ \\ ${ }^{1) 2) 3)}$ STKIP Singkawang \\ E-mail: $\underline{\text { sakillahk@gmail.com }}^{1)}$, fitri.raisahama@gmail.com ${ }^{2)}$ zulfahita_syakila@ @mail.com $^{3)}$
}

Diterima 08 Juli 2021, direvisi 11 Agustus 2021, diterbitkan 31 September 2021

\begin{abstract}
Abstrak
Tujuan penelitian ini untuk mendeskripsikan Nilai Budaya dalam Cerita Rakyat Masyarakat Melayu Kabupaten Mempawah meliputi sebagai berikut. Nilai budaya hubungan manusia dengan Tuhan, nilai budaya hubungan manusia dengan alam, nilai budaya dalam hubungan manusia dengan masyarakat, nilai budaya hubungan manusia dengan diri sendiri dan implementasi cerita rakyat masyarakat melayu Kabupaten Mempawah dalam rencana pelaksanaan pembelajaran di sekolah. Metode yang digunakan dalam penelitian ini, yaitu metode deskriptif. Sumber data dalam penilitian ini merupakan nilai budaya dalam cerita rakyat masyarakat Melayu Kabupaten Mempawah yang dituturkan oleh seorang masyarakat Melayu Kabupaten Mempawah. Teknik yang digunakan dalam penelitian ini adalah teknik rekam. Instrumen utama dalam penelitian ini adalah peneliti sendiri dengan alat bantu yakni alat rekam berupa handphone. Teknik pengecekan keabsahan data menggunkan teknik kecukupan referensial, teknik triangulasi, dan ketekunan. Hasil penelitian dalam nilai budaya dalam cerita rakyat masyarakat Melayu Kabupaten Mempawah di bagi menjadi 4 yaitu nilai budaya yang berhubungan dengan Tuhan memiliki 5 nilai sikap sebanyak 6 data, nilai budaya yang berhubungan dengan alam terdiri dari 2 nilai sikap sebanyak 5 data, nilai budaya yang berhubungan dengan manusia dengan masyarakat terdiri 11 sikap sebanyak 14 data, dan nilai budaya hubungan manusia dengan dirinya sendiri terdiri dari 10 sikap sebanyak 14 data.
\end{abstract}

\section{Kata Kunci : Nilai Budaya, Cerita Rakyat}




\section{PENDAHULUAN}

Sastra lisan adalah sebuah karya hasil pemikiran seseorang yang bersifat imajinasi manusia. Penting memahami sastra lisan, karena jenis sastra ini berfungsi sebagai wadah hikmat tradisional yang mengandung konvensi, sistem nilai, adat istiadat dan berbagai norma yang berlaku dalam masyarakat itu. Seperti yang diungkapkan Vansina (dalam Emzir dan Rohman, 2016: 212), sastra lisan ibarat kata-kata mutiara yang menjadi kunci memahami filosofi kerja, cinta, dan penderitaan leluhur kita dimasa lalu.

Sastra lisan merupakan bagian dari kehidupan sastra yang memiliki posisi sangat penting dalam masyarakat. Sastra lisan terdiri dari beberapa bentuk antara lain bahasa rakyat, ungkapan rakyat, puisi rakyat, cerita rakyat, maupun nyanyian rakyat. Satu di antara bentuk sastra lisan adalah cerita rakyat. Cerita rakyat merupakan cerita yang berasal dari masyarakat dan berkembang dalam masyarakat pada masa lampau yang menjadi ciri khas disetiap bangsa yang mempunyai kultur budaya yang beraneka ragam yang mencakup kekayaan budaya dan sejarah yang dimiliki masing-masing bangsa. Pada umumnya cerita rakyat ini mengisahkan mengenai suatu kejadian di suatu tempat atau asal muasal suatu tempat. Tokoh-tokoh yang dimunculkan dalam cerita rakyat umumnya diwujudkan dalam bentuk binatang, manusia dan dewa.

Cerita rakyat masyarakat Melayu Kabupatan Mempawah menceritakan kebudayaan masyarakat Melayu Kabupaten Mempawah pada masa kerajaan dengan berlatarkan kehidupan masyarakat dimasa lampau yang masih hidup secara tradisional sebagai sarana penceritaan. Kebudayaan melayu diceritakan masyarakat di Kabupaten Mempawah melalui sembilan judul cerita rakyat. Adapun cerita rakyat yang akan diteliti peneliti berjumlah sembilan cerita rakyat yang berasal dari Kabupaten Mempawah Adapun cerita yang akan diteliti penulis yaitu (1) Raja Kodong, (2) Asal Usul Robo-robo, (3) Dara Hitam, (4) Panglima Sejati, (5) Kris Ajaib, (6) Habib Husen Al Qadri dan Asal Usul Galahrang, (7) Syeh Ali Bin Faqih, (8) Si Gonda, dan (9) Selusin Meriam Kuno.

Adapun yang menjadi pertimbangan peneliti memilih nilai budaya dalam cerita rakyat masyarakat Melayu Kabupaten Mempawah pertama, penulis ingin mengetahui nilai-nilai budaya yang ada didalam cerita rakyat masyarakat melayu Kabupaten Mempawah sehingga dapat dijadikan bahan pembelajaran. Kedua, nilai budaya merupakan teori yang dekat dengan kesaharian masyarakat sehingga sangat menarik untuk di gali melalui cerita rakyat.

Penelitian ini bertujuan untuk Pendeskripsian nilai budaya dalam hubungan manusia dengan Tuhan pada cerita rakyat masyarakat Melayu Kabupaten Mempawah, pendeskripsian nilai budaya dalam hubungan manusia dengan alam pada cerita rakyat masyarakat Melayu Kabupaten Mempawah, pendeskripsian nilai budaya dalam hubungan manusia dengan masyarakat pada cerita rakyat masyarakat Melayu Kabupaten Mempawah, Pendeskripsian nilai budaya dalam hubungan manusia dengan diri sendiri pada cerita rakyat masyarakat Melayu Kabupaten Mempawah, dan Pendeskripsian implementasi hasil penelitian dalam rencana pelaksanaan pembelajaran di sekolah.

\section{METODE}

Metode penelitian adalah suatu cara ilmiah untuk mendapatkan data dengan tujuan dan kegunaan tertentu. Dalam penelitian ini peneliti menggunakan metode deskriptif. Metode deskriptif adalah metode yang dilakukan dengan jalan menganalisis data yang sudah dikumpulkan berupa kata-kata, gambar, dan bukan angka-angka (Moleong, 2017:17).

Dalam penelitian ini bentuk penelitian yang digunakan oleh peneliti adalah penelitian kualitatif. Menurut Endraswara (2008:5) Penelitian kualitatif dilakukan dengan tidak mengutamakan angka-angka, tetapi mengutamakan kedalaman penghayatan terhadap interaksi antar konsep yang sedang dikaji secara empiris.

Pendekatan yang digunakan dalam penelitian ini adalah pendekatan antropologi. Pendekatan antropolgi merupakan ilmu tentang manusia khususnya asal-usul, aneka warna 
bentuk fisik, adat istiadat, dan kepercayaan pada masa lampau. Menurut Endaswara (2008:107) Pendekatan antropologi meneliti karya sastra dari segi pandang endrografi, yaitu untuk melihat aspek-aspek budaya masyarakat.

Dalam penelitian ini peneliti mendapatkan data melalui dua informan yang merupakan penduduk asli setempat dan memiliki pengetahuan mengenai cerita rakyat. Teknik pengumpulan data yang peneliti gunakan untuk memperoleh data dan informasi dalam penelitian ini adalah teknik komunikasi langsung/wawancara, tehnik rekam dan teknik catat. Alat pengumpul data adalah alat yang digunakan untuk mengumpulkan data. Pada penelitian ini alat pengumpul data yang digunakan penulis adalah Human Instrument dan Lembar Wawancara, alat perekam dan kartu data. tahapan-tahapan analisis dalam penelitian ini adalah Cerita rakyat yang sudah ditraskripkan ke dalam bentuk tulisan dibaca dengan pembacaan pemahaman, yaitu dengan melakukan proses pembacaan dan memahami teks bacaan berupa cerita rakyat masyarakat Melayu, kemudian dianalisis satu pesatu dan dikelompokan berdasarkan katagori nilai budaya, setelah dilakukan penganalisisan data berupa cerita rakyat masyarakat Melayu Kabupaten Mempawah maka hasil analisis dikaji ulang dengan mendiskusikan hasil penelitian kepada dosen pembimbing dan teman sejawat, menyimpulkan hasil penelitian. Dalam penelitian ini teknik pemeriksaan keabsahan data yang digunakan adalah trianguasi, Ketekunan/keajengan pengamatan dan pemeriksaan teman sejawat.

\section{HASIL DAN PEMBAHASAN}

Hasil penelitian yang terdapat dalam nilai budaya dalam cerita rakyat masyarakat Melayu Kabupaten Mempawah dibagi menjadi empat. Pertama, Nilai budaya hubungan manusia dengan tuhan. Kedua, nilai budaya hubungan manusia dengan alam. Ketiga, Nilai budaya hubungan manusia dengan sesama manusia. Keempat, Nilai budaya hubungan manusia dengan diri sendiri pada cerita rakyat masyarakat Melayu Kabupaten Mempawah. Kelima, Implementasi hasil penelitian dalam rencana pelaksanaan pembelajaran di sekolah.

A. Nilai Budaya dalam Hubungan Manusia dengan Tuhan dalam Cerita Rakyat Masyarakat Melayu Kabupaten Mempawah

\section{Berserah Diri}

Berserah diri kepada Tuhan merupakan sikap manusia untuk menyerahkan dirinya secara total kepada Tuhan atau kekuatan tertinggi yang disembah. Nilai budaya berserah diri dalam cerita rakyat masyarakat Melayu Kabupaten Mempawah ditemukan dalam cerita rakyat Syeh Ali Bin Faqih. Nilai budaya tersebut ditunjukan melalui data sebagai berikut.

\section{Cerita Rakyat 7 Syeh Ali Bin Faqih}

\section{Data 1}

"die hanye berpasrah dirik kepade Allah sajak" (Anonim)

Terjemahan:

"dia hanya berpasrah diri kepada Allah saja"

Berdasarkan kutipan tersebut, sikap berserah diri memiliki bentuk penyerahan diri sepenuhnya kepada Tuhan agar dilindungi dari segala macam hal yang dapat membahayakannya.

\section{Data 2}

"Syeh Ali Bin Faqeh tadi ni hanye mampulah bedoe kepade Allah berserah dirik" (Anonim)

Terjemahan:

"Syeh Ali Bin Faqih hanya mampu berdoa kepada Allah berserah diri"

Berdasarkan kutipan tersebu cerita rakyat Syeh Ali Bin Faqih ini memiliki sikap berserah diri kepada Tuhan atas segala sesuatu yang akan terjadi kepada dirinya dan 
keluarganya yang sedang berada bersamanya dalam perjalanan menuju Mempawah.

\section{Meminta Perlindungan dan Pertolongan pada Tuhan}

Meminta perlindungan dan pertolongan kepada Tuhan berhubungan dengan sikap religius manusia yang mempercayai bahwa Tuhan adalah penguasa alam semesta (Sunoto,2017:34). Nilai budaya meminta perlindungan dan pertolongan kepada Tuhan dalam cerita rakyat masyarakat Melayu Kabupaten Mempawah ditemukan dalam cerita rakyat Asal Usul Robo-robo dan cerita rakyat Syeh Ali Bin Faqih. Nilai budaya tersebut ditunjukan melalui data sebagai berikut.

Cerita Rakyat 2 Asal Usul Robo-robo

Data 3

"doe bersame memohon kepade Allah supaye dijaohkan dari balak dan bencane dan sekaligus memintak keselamatan dunie akherat"' (Anonim)

Terjemahan:

"doa bersama memohon kepada Allah supaya dijauhkan dari bala dan bencana dan sekaligus minta keselamatan dunia akhirat"

Dari kutipan tersebut, sikap meminta perlindungan dan pertolongan kepada Tuhan dilihat dari bentuk berdoa kepada Tuhan agar terhidar dari bala, bencana dan meninta keselamatan dunia akhirat.

Data 4

"meminta kepade Allah supaye di jauhkan dari hal-hal yang burok" (Anonim)

Terjemahan:

"meminta kepada Allah supaya di jauhkan dari hal-hal yang buruk".

Dari kutipan tersebut, sikap meminta perlindungan dan pertolongan kepada Tuhan dilihat pada kutipan meminta kepada Tuhan agar terhidar dari hal-hal yang buruk. Kutipan diatas memang tidak jauh berbeda dengan kutipan pertama tapi kutipan diatas menjelaskan bahwa kejadian di masa lampau masih di lakukan hingga sekarang.

\section{Cerita Rakyat 7 Syeh Ali Bin Faqih}

Data 5

"Syeh Ali Bin Faqeh tadi ni hanye mampulah bedoe kepade Allah berserah Terjemahan:

dirik" (Anonim)

"Syeh Ali Bin Faqih hanya mampulah bedoa kepada Allah beserah diri"

Dari kutipan tersebut dapat dilihat kesamaan dengan kutipan nilai budaya sikap beserah diri namun dalam kutipan ini juga memiliki nilai budaya sikap meminta perlindungan dan pertolongan kepada Tuhan dilihat pada kutipan Syeh Ali Bin Faqih yang berdoa kepada tuhan meminta keselamatan.

3. Mempercayai Kebaikan dan Keburukan Berasal dari Tuhan

Nilai budaya mempercayai kebaikan dan keburukan berasal dari Tuhan berhubungan dengan kepercayaan manusia terhadap takdir. Nilai budaya mempercayai kebaikan dan keburukan berasal dari Tuhan dalam cerita rakyat masyarakat Melayu Kabupaten Mempawah ditemukan dalam cerita rakyat Asal Usul Robo-robo. Nilai budaya tersebut ditunjukan melalui data sebagai berikut.

\section{Cerita Rakyat 2 Asal Usul Robo-robo}

Data 6

"meminta kepade Allah supaye di jauhkan dari hal-hal yang burok" (Anonim)

Terjemahan :

"meminta kepada Allah supaya di jauhkan dari hal-hal yang buruk" 
Dari kutipan tersebut, mempercayai kebaikan dan keburukan berasal dari Tuhan dilihat dari kepercayaan masyarakat bahwa dengan mengadakan makan-makan bersama pada bulan syafar dan meminta kepada Tuhan agar dijauhkan dari hal-hal yang buruk.

4. Mempercayai Hidup dan Mati Kepada Tuhan

Mempercayai hidup dan mati kepada tuhan berisi kepercayaan bahwa hidup dan mati adalah milik Tuhan, (Silaeman dalam Sunoto, 2017:37). Nilai budaya mempercayai mempercayai hidup dan mati kepada tuhan dalam cerita rakyat masyarakat Melayu Kabupaten Mempawah ditemukan dalam cerita rakyat Syeh Ali Bin Faqih. Nilai budaya tersebut ditunjukan melalui data sebagai berikut.

Cerita Rakyat 7 Syeh Ali Bin Faqih

Data 7

"tebareng dalam keadaan selamat die pon merase sangat bersyukor kepade Allah" (Anonim)

Terjemahan:

"tebaring dalam keadaan selamat dia pun merasa sangat bersyukur kepada Allah"

Dari kutipan tersebut, sikap mempercayai hidup dan mati kepada Tuhan dilihat dari sikap dia bersyukur atas keselamatan anaknya yang terlempar dan terdampar ditepian pantai.

\section{Sikap Saleh}

Sikap Saleh adalah sikap mencurahkan perhatian untuk bertindak berdasarkan ketaatan kepada ajaran agama atau pemenuhan terhadap kewajiban-kewajiban agama, tulus, ikhlas (Samani dan Hariyanto, 120:2017). Nilai budaya sikap saleh dalam cerita rakyat masyarakat Melayu Kabupaten Mempawah ditemukan dalam cerita rakyat Habib Husen Al-Qadri. Nilai budaya tersebut ditunjukan melalui data sebagai berikut Cerita rakyat 6 Habib Husen Al-Qadri

\section{Data 8}

"masyarakat yang mengetaui bahwe ulama besar Habib Husin Al-Qadri ini telah tinggal di Mempawah Beramai-ramai pegi ke Habib Husin Al-Qadri tu untok belajar agame" (Anonim)

Terjemahan:

"masyarakat yang mengetahui bahwa ulama besar Habib Husin Al-Qadri ini telah tinggal di Mempawah beramai-ramai pergi kepada Habib Husin Al-Qadri untuk belajar agama"

Kutipan tersebut menjelaskan bahwa, sikap saleh orang-orang atau masyarakat pada saat itu sangat bersemangat untuk belajar agama.

B. Nilai Budaya dalam Hubungan Manusia dengan Alam dalam Cerita Rakyat Masyarakat Melayu Kabupaten Mempawah

1. Percaya Adanya Mahluk Gaib di Alam Semesta

Percaya adanya mahluk gaib di alam semesta merupakan keyakinan yang mengandung konsepsi tentang adanya dewa, mahluk halus, seperti roh leluhur, dan konsepsi tentang yang tinggi dan penciptaan alam, (Sujarwa dalam Sunoto, 2017:38). Nilai budaya Percaya adanya mahluk gaib di alam semesta dalam cerita rakyat masyarakat Melayu Kabupaten Mempawah ditemukan dalam cerita rakyat Raja Kodong dan cerita rakyat Keris Ajaib. Nilai budaya tersebut ditunjukan melalui data sebagai berikut.

\section{Cerita Rakyat 1 Raja Kodong}

Data 1

"melaksanakan ritual buang-buang dan bertemulah raje dengan Putri Banyumastari dengan wujud buaya kuning" (Anonim) 
Terjemahan:

"melaksanekan ritual buang-buang dan bertemulah raja dengan Putri

Banyumastari dengan wujud buaya kuning"

Kutipan tersebut menjelaskan bahwa, sikap percaya adanya mahluk gaib di alam semesta mempunyai kepercayaan tentang adanya mahluk gaib didaerah tersebut. Kepercayaan bahwa Raja menikah dengan mahluk gaib berupa seekor budaya kuning yang di percaya merupakan putri penguasa sungai Mempawah.

\section{Cerita Rakyat 5 Keris Ajaib}

Data 2

"seorang laki-laki dan laki-laki itu adalah jelmaan dari kris ajaib yang apebile malam hari keris itu berubah menjadi seorang pemuda yang amat Terjemahan: tampan" (Anonim)

"seorang laki-laki dan laki-laki itu adalah jelmaan dari keris ajaib yang apa bila malam hari keris itu berubah menjadi seorang pemuda yang amat tampan"

Kutipan tersebut menjelaskan bahwa, sikap percaya adanya mahluk gaib di alam semesta mempunyai kepercayaan tentang adanya mahluk gaib didaerah tersebut. Kepercayaan bahwa sebuah keris yang dapat berubah menjadi seorang manusia di malam hari.

2. Saling Menghormati dan Saling Menjaga Antar Sesama Mahluk Hidup

Saling menghormati dan saling menjaga hubungan dengan sikap manusia untuk menghargai keberagangan (Sunoto, 2017:40). Nilai budaya saling menghormati dan saling menjaga antar sesama mahluk hidup dalam cerita rakyat masyarakat Melayu Kabupaten Mempawah ditemukan dalam cerita rakyat Raja Kodong, cerita rakyat Asal Usul Robo-robo dan cerita rakyat Habib Husen Al Qadri. Nilai budaya tersebut ditunjukan melalui data sebagai berikut.

\section{Cerita Rakyat 1 Raja Kodong}

Data 3

"sebagai pengingat bahwe selaen kite manusie juga ade mahlok laen yang ade di muke bumi ini juge sebangai peringatan mengenang cerite raje kodong ni" (Anonim)

Terjemahan:

"sebagai pengingat bahwa selain kita manusia juga ada mahluk lain yang ade di muka bumi ini dan jug sebagai peringatan mengenang cerita Raja Kodong ni".

Dari kutipan tersebut, sikap menghormati dan menjaga hubungan sesama mahluk hidup tergambar dari masih digelarnya acara buang-buang hingga sampai saat ini bentuk menghormati dan menjaga tergambar melalui ritual buang-buang yang masih di lakukan secara turun temurun.

\section{Cerita Rakyat 2 Asal Usul Robo-robo}

Data 4

"di sambot dengan suke cite oleh masyarakat Mempawah kala itu sehingge membuat Empu Daeng Menambon dan istrinye merase sangat senang Empu Daeng Menambon pon ngasikan makanan yang die bawaknye berupe ketupat kepade masyarakat mempawah" (Anonim)

Terjemahan :

"di sambut dengan suka cita oleh masyarakat Mempawah pada saat itu sehingga membuat Opu Daeng Menambon dan istrinya merasa sangat senang. Opu Daeng Menambonpun memberikan makanan yang dia bawa berupa ketupat kepada masyarakat Mempawah" 
Dari kutipan tersebut, sikap menghormati dan menjaga hubungan sesama mahluk hidup tergambar dari bentuk penghormatan masyarakat Mempawah pada saat kedatangan Opu Daeng Menambon yang di sambut dengan suka cita dan bentuk penghormati juga tergambar dari perilaku Opu Daeng yang langsung memberikan bekalnya kepada masyarakat yang menyambutnya.

\section{Data 5}

"sekaligus mengenang kedatangan Empu Daeng Menambon pertame kali di sampai die wafat pade bulan syafar" (Anonim)

Terjemahan:

"sekaligus mengenang kedatangan Opu Daeng Menambong pertama kali sampai die wafat pada bulan syafar".

Dari kutipan tersebut, sikap menghormati dan menjaga hubungan sesama mahluk hidup tergambar dari masih digelarnya acara robo-robo hingga sampai saat ini bentuk menghormati dan menjaga tergambar melalui ritual robo-robo yang masih di lakukan dari generasi ke generasi.

\section{Cerita Rakyat 6 Habib Husen Al Qadri}

Data 6

"keputusan ini pun di sambot dengan suke cite oleh Empu Daeng Menambon yang mase itu memerintah di kerajaan Mempawah kala ini kala itu Habib Husen Al Qadri meminta sebuah tempat tinggal dan sebuah surau sebagai sebagai tempat untok mengajarkan agame islam perintah itupon langsong di penohek oleh Empu Daeng Menambon setelah di bangonye sebuah surau dan tempat tinggal di Mempawah Empu Daeng Menambon lalu pegi untok menyempot Habib Husen Al Qadri dari kerajaan Matan Sukadane" (Anonim)

Terjemahan:

"keputusan inipun disambut dengan suka cita oleh Opu Daeng Menambon yang pada masa itu memerintah di kerajaan Mempawah waktu itu Habib Husin Al Qadri meminta sebuah tempat tinggal dan sebuah surau sebagai tempat untuk mengajarkan agama islam pemintaan itupun langsung dipenui oleh Opu Daeng Menambon, setelah dibangunya sebuah surau dan tempat tinggal di Mempawah Opu Daeng Menambon lalu pergi untuk menyemput Habib Husin Al Qadri dari kerajaan Matan Sukadane"

Dari kutipan tersebut, sikap menghormati dan menjaga hubungan sesama mahluk hidup tergambar dari bentuk penghormatan Opu Daeng Menambon terhadap Habib Husen Al Qadri yang merupakan salah satu ulama besar pada saat itu. Semua yang dibutuhkan Habib Husen Al Qadri langsung di penuhi Opu Daeng Menambon.

C. Nilai Budaya dalam Hubungan Manusia dengan Masyarakat dalam Cerita Rakyat Masyarakat Melayu Kabupaten Mempawah

\section{Tidak Mengambil Milik Orang Lain}

Sikap tidak mengambil milik orang lain adalah sikap dimana seseorang tidak ingin memiliki atau merebut suatu benda atau barang milik orang lain. Nilai budaya tidak mengambil milik orang lain dalam cerita rakyat masyarakat Melayu Kabupaten Mempawah ditemukan dalam cerita rakyat Si Gonda. Nilai budaya tersebut ditunjukan melalui data sebagai berikut.

\section{Cerita Rakyat 8 Si Gonda}

Data 1

"waktu dolok mau di rebot oleh pasukan belande Si Gonda ini di bakar sampai berhari-hari tapi be anehnye meriam ini tak berubah warne" (Anonim)

Terjemahan: 
"waktu dulu mau di rebut oleh pasukan belanda Si Gonda ini dibakar sampai

berhari-hari tapi anehnya meriam ini tidak berubah warna".

Dalam kutipan tersebut, sikap tidak mengambil milik orang lain tergambar dari sikap Belanda yang mengembalikan kembali meriam Si Gonda ke istana Amantubillah.

\section{Data 2}

"Si Gonda ni pun pernah di ambek pakse oleh polisi jepang" (Anonim)

Tejemahan:

"Si Gonda ini pun pernah di ambil paksa oleh polisi Jepang"

Dalam kutipan tersebut, sikap tidak mengambil milik orang lain tergambar dari sikap polisi-polisi yang mengembalikan kembali meriam Si Gonda ke istana Amantubillah dan dalam kutipan ini terdapat pesan bahwa tidak baik mengambil milik orang lain.

2. Menghormati Penyandang Kekuasaan

Menghormati penyandang kekuasan adalah keinginan dan maksud untuk menghargai penyandang kekuasaan/pemerintah termasuk kepatuhan terhadap hukum dalam situasi tertentu yang sah (Samani dan Hariyanto, 130:2017). Sikap menghormati penyandang kekuasaan ini juga ditemukan dalam cerita rakyat masyarakat Melayu Kabupaten Mempawah dengan judul Raja Kodong, Dara Hitam, Panglima Sejati. Nilai budaya tersebut ditunjukan melalui data sebagai berikut.

\section{Cerita Rakyat 1 Raja Kodong}

Data 3

"Raje Kodong ni merupekan salah satu Raje yang memerintah di kerajaan Mempawah" (Anonim)

Terjemahan:

"Raja Kodong ini merupakan satu diantara Raja yang pernah memerintah di kerajaan Mempawah".

Dalam kutipan tersebut, sikap menghormati penyandang kekuasaan dapat dilihat dari kata Raja karena kata Raja ini mengambarkan bahwa Raja Kodong ini pernah memimpin pemerintahan dikerajaan Mempawah terdahulu.

\section{Data 4}

"seorang penguase sungai yang bername Putri Banyumastari" (Anonim)

Terjemahan:

"penguasa sungai yang bernama Putri Banyumastari"

Dalam kutipan tersebut, sikap menghormati penyandang kekuasaan dapat dilihat dari kata "penguasa" dan dalam kata "Putri" karena dalam kata penguasa ini menegaskan bahwa Putri Banyumastari adalah seorang yang berkuasa dan kata Putri melambangkan bahwa Putri Banyumastari ini merupakan orang yang memiliki kedudukan.

\section{Cerita Rakyat 3 Dara Hitam}

Data 5

"raje pertame di pemembahan Senggok" (Anonim)

Terjemahan:

"raja pertama di penembahan Senggok"

Dalam kutipan tersebut, sikap menghormati penyandang kekuasaan dapat dilihat dari kata "Patih" yang menegaskan bahwa Patih Gumantar adalah seorang pemimpin dan ditegaskan kembali dengan kata "Raja" sehingga dapat terlihat dengan jelas bahwa nilai menghormati penyandang kekuasan terdapat dalam kutipan tersebut.

\section{Cerita Rakyat 4 Panglima Sejati}

Data 6

"Panglima sejati ni sebenarnye adalah gelar yang diberekan seorang Raje pade pemerintah Senggok kepada seorang Datok Petinggi” (Anonim) 
Terjemahan:

"panglima sejati ini sebenarnya adalah gelar yang diberikan seorang Raja kepada seorang Datok Petinggi”.

Dalam kutipan tersebut, sikap menghormati penyandang kekuasaan dapat dilihat dari kalimat memberikan galar didalam kutipan tersebut sangat jelas bahwa seorang raja yang sangat menghormati seorang Datok Petinggi sehingga dia memberikan gelar panglima sejati kepada Datok Petinggi tersebut.

\section{Suka Membantu}

Suka membantu adalah sikap dan sifat untuk siap membantu orang lain yang memerlukan pertolongan (Samani dan Hariyanto, 124:2017). Sikap suka membantu ini juga ditemukan dalam cerita rakyat masyarakat Melayu Kabupaten Mempawah dengan judul Raja Kodong. Nilai budaya tersebut ditunjukan melalui data sebagai berikut.

\section{Cerita Rakyat 1 Raja Kodong}

Data 7

"pengawalnyepun ikut bantuk e tapi tak bise terangkat ugak" (Anonim)

Terjemahan:

"pengawanyapun ikut menolong tetapi tidak terangkat juga"

Dalam kutipan tersebut, sikap suka membantu dapat dilihat dari kalimat pengawalnyapun ikut menolong tanpa perintah para pengawal dengan suka rela menolong rajanya untuk menaikan jala itu.

\section{Penuh Kasih Sayang}

Penuh kasih sayang adalah memiliki dan menunjukkan perasaan penuh kasih sayang, mencintai dan bersikap penuh kelembutan (Samani dan Hariyanto, 116:2017). Sikap penuh kasih sayang ini juga ditemukan dalam cerita rakyat masyarakat Melayu Kabupaten Mempawah dengan judul Raja Kodong dan Keris Ajaib. Nilai budaya tersebut ditunjukan melalui data sebagai berikut.

\section{Cerita Rakyat 1 Raja Kodong}

Data 8

"raje merase sangat rindu dengan rakyat dan keluargenye yang ade didaratan Mempawah, Rajepon maok balek dan bawak Putri Banyumastari bersamenye" (Anonim)

Terjemahan:

"raja merasa sangat rindu dengan rakyatnya dan keluargaanya yang ada didaratan Mempawah, rajapun ingin pulang dan membawa beserta Putri Banyumastari"

Dalam kutipan tersebut, sikap penuh kasih sayang dapat dilihat dari kalimat yang menunjukan rasa rindu Raja terhadap rakyat dan keluarga, sikap penuh kasih sayang juga ditunjukan dari kalimat raja yang ingin membawa istrinya Putri Banyumastari pulang kedaratan.

\section{Cerita Rakyat 5 Keris Ajaib \\ Data 9}

"Dara Rode ini merupekan putri kesayangan Raje, die di kawal oleh tujoh pengawal dan di layani oleh tujoh pelayan sehingge tak satupon laki-laki yang dapat melihat kecantekannye". (Anonim)

Terjemahan:

"Dara Rode ini merupakan putri kesayangan Raja, dia dikawal oleh tujuh pengawal dan dilayani oleh tujuh pelayan sehingga tidak ada satupun laki-laki yang bisa melihat kecantikan Dara Rode" 
Dalam kutipan tersebut, sikap penuh kasih sayang ditunjukan oleh Raja kepada anaknya melalui pengawalan yang ketat dan pelayan yang banyak sehingga anaknya ini aman dan tak satu laki-lakipun yang bisa melihat kecantikan anaknya.

\section{Ketangguhan}

Ketangguhan adalah sukar dikalahkan dan tidak mudah menyerah dalam mewujudkan cita-cita atau suatu tujuan (Samani dan Hariyanto, 131:2017). Sikap ketangguhan ini juga ditemukan dalam cerita rakyat masyarakat Melayu Kabupaten Mempawah dengan judul Dara Hitam. Nilai budaya tersebut ditunjukan melalui data sebagai berikut.

\section{Cerita Rakyat 3 Dara Hitam \\ Data 10}

"Sehingga kepalak Patih Gumantar yang kalah pade pertempuran itu dibawak olah Raje Miaju yang berhasel mengalahkan Patih Gumantar" (Anonim)

Terjemahan:

"Sehingga kepala Patih Gumantar yang kalah pada pertempuran itu dibawa oleh Raja Miaju yang berhasil mengalahkan Patih Gumantar"

Dalam kutipan tersebut, sikap ketangguhan ditunjukan pada kalimat kepala Patih Gumantar di bawa oleh Raja Miaju yang menang dalam perang kayau mengayau memperlihatkan ketangguhan seorang Raja yang menang dalam perang.

\section{Perhatian}

Perhatian adalah sikap menunjukkan perhatian kepada seseorang atau kepada tugas sepenuhnya (Samani dan Hariyanto, 116:2017). Sikap kepedulian ini juga ditemukan dalam cerita rakyat masyarakat Melayu Kabupaten Mempawah dengan judul Dara Hitam. Nilai budaya tersebut ditunjukan melalui data sebagai berikut.

\section{Cerita Rakyat 3 Dara Hitam}

\section{Data 11}

Terjemahan:

"die pon berlari untok meliat keadaan Raje" (Anonim)

"dia pun berlari untuk melihat Raja"

Dalam kutipan tersebut, sikap perhatian ditunjukan pada kalimat dia berlari melihat keadaan Raja, dari kalimat itu dapat diketahuai sikap peduli dari Dara Hitam terhadap Raja.

7. Cinta, suka

Cinta, suka adalah suatu perasaan yang diwujudkan dalam sikap dan prilaku yang mencerminkan kasih sayang yang dalam dan penuh kelembutan terhadap orang lain, sehingga timbul perasaan memiliki satu sama lain (Samani dan Hariyanto, 125:2017). Sikap cinta, suka ini juga ditemukan dalam cerita rakyat masyarakat Melayu Kabupaten Mempawah dengan judul Dara Hitam. Nilai budaya tersebut ditunjukan melalui data sebagai berikut.

\section{Cerita Rakyat 3 Dara Hitam}

Data 12

"Karena Raje udah jatuh cinte kepade Dara Itam die pun menyetujuinye" (Anonim)

Terjemahan:

"Karena Raja sudah jatuh cinta kepada Dara Hitam diapun menyetujuainya"

Dalam kutipan tersebut, sikap cinta, suka ditunjukan pada kalimat karena Raja sudah jatuh cinta, dari kalimat itu dapat diketahuai sikap cinta, suka Raja kepada Dara Hitam sehingga dia menyetujui syarat dari Dara Hitam selain itu sikap Raja yang setuju akan syarat dari dara hitam ini dapat diketahui bahwa Raja ingin memiliki Dara hitam. 


\section{Kesetiaan}

Kesetiaan adalah sikap memanfaatkan suatu situasi dengan berupaya sepenuh hati untuk menunjukkan komitmen kepada mereka yang dilayani (Samani dan Hariyanto, 126:2017).

\section{Cerita Rakyat 4 Panglima Sejati} Data 13

"Datok pon maok menerimak perintah Raje." (Anonim)

Terjemahan:

"Datok pun mau menerima perintah"

Dalam kutipan tersebut, sikap kesetiaan ditunjukan pada kutipan diatas pada saat Datok menrima perintah Raja dan bersumpah bahkan dengan nyawanya sudah menjelaskan betapa setianya Datok kepada Raja.

\section{Kebijaksanaan}

Kebijaksanaan adalah sikap mengenal dan menjahui kata-kata, tindakan, dan sikap yang dapat menimbulkan akibat-akibat yang tidak diinginkan, atau dapat menyakiti hati orang lain (Samani dan Hariyanto, 121:2017). Sikap kebijaksanaan ini juga ditemukan dalam cerita rakyat masyarakat Melayu Kabupaten Mempawah dengan judul Panglima Sejati. Nilai budaya tersebut ditunjukan melalui data sebagai berikut.

\section{Cerita Rakyat 4 Panglima Sejati}

Data 14

"Raje memaklumi hal itu." (Anonim)

Terjemahan:

"Raja memaklumi hal itu"

Dalam kutipan tersebut, kebijaksanaa ditunjukan pada kutipan diatas pada saat Raja yang memaklumi kesalahan Datok dan tidak marah ataupun memberikan hukuman kepada Datok Petinggi.

\section{Kejujuran}

Kejujuran adalah sikap menjujung tinggi kebenaran, ikhlas dan lurus hati, tidak suka berbohong, mencuri dan menfitnah, tidak pernah bermaksud menjerumuskan orang lain (Samani dan Hariyanto, 132:2017). Budaya kejujuran ini juga ditemukan dalam cerita rakyat masyarakat Melayu Kabupaten Mempawah dengan judul Keris Ajaib. Nilai budaya tersebut ditunjukan melalui data sebagai berikut.

\section{Cerita Rakyat 5 Keris Ajaib}

\section{Data 15}

"die mengakui bahwe memang betol die di temani oleh seorang laki-laki dan laki-laki itu adalah jelmaan dari Keris Ajaib." (Anonim)

\section{Terjemahan:}

"dia mengakui bahwa memang benar dia ditemani oleh seorang laki-laki dalam laki-laki itu adalah jilmaan dari Keris Ajaib"

Dalam kutipan tersebut, sikap jujur dapat dilihat dari kejujuran Dara Ronde kepda ayahnya.

\section{Sikap Suka Kerja Sama Gotong Royong}

Sikap suka kerja sama gotomg royong adalah tindakan dan sikap mau bekerja sama dengan orang lain untuk mencapai tujuan besama keuntungan bersama (Samani dan Hariyanto, 126:2017). Gotong royong ini juga ditemukan dalam cerita rakyat masyarakat Melayu Kabupaten Mempawah dengan judul Selusin Meriam Kuno. Nilai budaya tersebut ditunjukan melalui data sebagai berikut. 


\section{Cerita Rakyat 9 Selusin Meriam Kuno \\ Data 16}

"pertemporan penembahan Adijaya dan rakyatnye Mempawah ni melawan

Belande "(Anonim)

Terjemahan:

"pertempuran penembahan Adijaya dan rakyat Mempawah melawan Belanda"

Dalam kutipan tersebut, kerja sama atau gotong royong ditunjukan pada kutipan diatas yang menyatakan perjuangan penembahan Adijaya dan rakyatnya hal ini membuktikan adanya kerja sama antara penembahan Adijaya dan rakyatnya dalam peperangan atau pertempuran.

D. Nilai Budaya dalam Hubungan Manusia dengan Diri Sendiri dalam Cerita Rakyat Masyarakat Melayu Kabupaten Mempawah

1. Kerja Keras

Kerja keras adalah salah satu upaya yang terus dilakukan atau tidak pernah menyerah dalam menyelesaikan pekerjaan yang menjadi tugasnya sampai tuntas Nilai budaya kerja keras dalam cerita rakyat masyarakat Melayu Kabupaten Mempawah ditemukan dalam cerita rakyat Raja Kodong, Syeh Ali Bin Faqih dan Selusin Meriam Kuno. Nilai budaya tersebut ditunjukan melalui data sebagai berikut.

\section{Cerita Rakyat 1 Raja Kodong}

Data 1

"Raje Kodong pon maok menarek jalenye kepermukaan tapi jale itu terase berat sampai pengawalnyepun ikut bantuk e tapi tak bise terangkat ugak sampai akhernye Raje yelam untok melihat ape yang menehan jale $e$ "(Anonim)

Terjemahan:

"Raja Kodong ingin menarik jalanya kepermukaan tapi jala itu terasa berat sampai pengawalnyapun ikut membantu tapi tak bisa terangkat juga sampai akhirnya Raja menyelam untuk melihat apa yang menahan jalanya"

Dari kutipan tersebut, sikap kerja keras dilihat dari Raja Kodong yang tidak menyerah dalam menjala meski tak satupun tangkapan yang dia dapatkan dia terus menjala dan pada saat jalanya tersangkut dia pun menyelam untuk melihat apa yang menahan jalanya.

\section{Cerita Rakyat 7 Syeh Ali Bin Faqih}

Data 2

"Syeh Ali Bin Faqeh ni merupekan seorang ulamak yang pergi berlayar untok mencarek tempat gune menyebarkan agame islam setelah beberape bulan terombang ambing dilaotan besame istrinye singgahlah die di pulau" (Anonim)

Terjemahan:

"Syeh Ali Bin Faqih ini merupakan seorang ulama yang pergi berlayar untuk mencari tempat untuk menyebarkan agama islam setelah beberapa bulan terombang ambing dilautan besama istrinya singgahlah dia di pulau "

Dari kutipan tersebut, sikap kerja keras dilihat dari kegigihan Syeh Ali Bin Faqih dalam mencari tempat baru untuk mengajarkan agama islam sehingga sampai berbulan-bulan terombang ambing di lautan.

\section{Cerita Rakyat 9 Selusin Meriam Kuno}

Data 3

"pertempuran penembahan Adijaya dan rakyatnye Mempawah ini melawan Belande" (Anonim)

Terjemahan: 
"pertempuran penembahan Adijaya dan rakyatnya Mempawah melawan Belanda"

Dari kutipan tersebut, sikap kerja keras dilambangkan dari adanya selusin meriam kuno itu yang merupakan peninggalan penembahan Adijaya yang berjuang melawan Belanda.

\section{Sabar}

Sabar merupakan sikap tahan dan tidak mudah emosi dalam melakukan sesuatu (Hasjim dalam Sunoto, 2017:29). Nilai budaya kerja keras dalam cerita rakyat masyarakat Melayu Kabupaten Mempawah ditemukan dalam cerita rakyat Syeh Ali Bin Faqih. Nilai budaya tersebut ditunjukan melalui data sebagai berikut.

\section{Cerita Rakyat 7 Syeh Ali Bin Faqih}

Data 4

"Syeh Ali Bin Faqeh harus besabar karene kehilangan purinye" (Anonim)

Tejemahan:

"Syeh Ali Bin Faqih harus besabar karena kehilangan putrinya".

Kutipan tersebut, menjelaskan sikap sabar dilihat dari kepasrahan Syeh Ali Bin Faqih yang kehilangan anaknya di bawa oleh salah satu pemberontak yang pergi.

3. Tanggung Jawab

Tanggung jawab adalah sikap dan perilaku seseorang untuk melaksanakan tugas dan kewajiban sebagaimana dan seharusnya yang dilakukan terhadap diri sendiri, masyarakat, lingkungan, negara, serta tuhan. Nilai budaya tanggung jawab dalam cerita rakyat masyarakat Melayu Kabupaten Mempawah ditemukan dalam cerita rakyat Dara Hitam, Panglima Sejati, dan Keris Ajaib. Nilai budaya tersebut ditunjukan melalui data sebagai berikut.

\section{Cerita Rakyat 3 Dara Hitam}

Data 5

"dengan berat hati Rajepon memberikan Dara Itam kepade Ria Sinir sebagai pemenohan janji yang udah di ucapkan" (Anonim)

Terjemahan:

"Dengan berat hati Rajapun memberikan Dara Hitam kepada Ria Sinir sebagai pemenuhan janji yang sudah Raja ucapkan".

Dari kutipan tersebut, sikap bertanggung jawab dapat dilihat dari kebesaran hari Raja memberikan Dara Hitan kepada Ria Sinir untuk di jadikan istrinya sebagai bentuk tanggung jawab raja terhadap janji yang sudah ia ucapkan.

\section{Cerita Rakyat 4 Panglima Sejati}

Data 6

"tapi karene Datok Petinggi udah besumpah pade Raje ape bile die tak dapat kembali ke Istana dalam waktu sehari semalam nyawe tarohannye dan pantang bagi Datok Petinggi melanggar sumpahnye dihadapan Raje datok petinggipun bunuh diri" (Anonim)

Terjemahan:

"tapi karena Datok Petinggi sudah besumpah kepade raja apebila dia tak dapat kembali keistana dalam waktu sehari semalam nyawa taruhanya dan pantang bagi Datok Petinggi melanggar sumpahnya dihadapan Raja Datok Petinggipun bunuh diri".

Dari kutipan tersebut, sikap bertanggung jawab dapat dilihat dari pengorbanan jiwa dari Datok Petinggi sebagai pemenuhan simpah yang telah dia ucapkan.

\section{Cerita Rakyat 5 Keris Ajaib}

Data 7 
"anak itu punye kelebehan yang tak same dengan manusie biase bayi itu tak punye pusat dan di beri gelar oleh Raje Kodong dengan gelar penembahan indak berpusat" (Anonim)

Terjemahan:

"anak itu punya kelebihan yang tak sama dengan manusia biasa bayi itu tidak memiliki pusat dan di beri gelar oleh Raja Kodong dengan gelar penembahan indak berpusat".

Dari kutipan tersebut, sikap bertanggung jawab dapat dilihat dari pemberian gelar dari Raja Kodong kepada anak dari Dara Rode sebagai bukti bahwa anak tersebut akan menjadi pemimpin di kerajaan menggantikan Raja Kodong dan sebagai pemenuhan janji yang telah dia ucapkan pada saat ingin menikahkan Dara Rode dengan Keris Ajaib.

4. Menjaga Kebaikan Diri

Menjaga kebaikan diri merupakan sikap dan usaha manusia untuk menjaga kebaikan jasmani dan rohani (Sunoto,2017:31). Nilai budaya menjaga kebaikan diri dalam cerita rakyat masyarakat Melayu Kabupaten Mempawah ditemukan dalam cerita rakyat Dara Hitam. Nilai budaya tersebut ditunjukan melalui data sebagai berikut.

\section{Cerita Rakyat 3 Dara Hitam}

Data 8

"di simpan dan di jage oleh pare pengawal kerajaan karene kepalak itu di percaye punye banyak macam khasiat" (Anonim)

Terjemahan:

"di simpan dan di jaga oleh para pengawal kerajaan karena kepala itu di percaya punya banyak macam khasiat."

Dari kutipan tersebut, sikap menjaga kebaikan diri ini dapat dilihat dari kepercayaan Raja Miaju terhadap kekuatan dari kepala yang didapatkan melalui perang kayau mengayau sehingga kepala itu di jaga ketat oleh para pengawal karena di percaya memiliki berbagai macam khasiat.

\section{Kesederhanaan}

Kesederhanaan adalah suatu kualitas atau keadaan tentang bagaimana berlaku sederhana itu, tidak suka pamar dan bermewah-mewah, tidak brfikir melit dan rumut (Samani dan Hariyanto, 131:2017). Nilai budaya kesederhanaan dalam cerita rakyat masyarakat Melayu Kabupaten Mempawah ditemukan dalam cerita rakyat Asal Usul Robo-robo, dan Dara Hitam. Nilai budaya tersebut ditunjukan melalui data sebagai berikut.

\section{Cerita Rakyat 2 Asal Usul Robo-robo}

Data 9

Terjemahan:

"dengan menggunekan perahu" (Anonim)

"dengan menggunakan perahu".

Dari kutipan tersebut, nilai budaya kesederhanaan terlihat dalam kutipan tersebut yang menyatakan bahwa Opu Daeng dan Istrinya datang menggunakan perahu tentunya hal tesebut jauh dari kemewahan dan dari suatu hal yang belebihan.

\section{Cerita Rakyat 3 Dara Hitam}

Data 10

"Rajepun bangon dan melepaskan tali tamban sampan tu," (Anonim)

Terjemahan:

"Rajapun bangun dan melepaskan tali pengikat perahu" 
Dari kutipan tersebut, menjelaskan pada saat Dara Hitam nilai budaya kesederhanaan terlihat dalam kutipan yang menyatakan bahwa Rajapun bangun dan melepaskan tali pengikat perahu dari kalimat tersebut dapat diketahui latar tempat Raja dan Dara Hitam sedang berada di perahu bersama dan dari alat trasportasi yang mereka gunakan sama sekali tidak menunjukan kemewahan dan tidak menunjukan hal-hal yang berlebihan.

6. Kebahagiaan

Kebahagiaan adalah suatu kualitas dimana hadir kenangan, ketentraman, dan kepuasan terhadap apa-apa yang telah dicapai (Samani dan Hariyanto, 124:2017). Nilai budaya kebahagiaan dalam cerita rakyat masyarakat Melayu Kabupaten Mempawah ditemukan dalam cerita rakyat Asal Usul Robo-robo. Nilai budaya tersebut ditunjukan melalui data sebagai berikut.

\section{Cerita Rakyat 2 Asal Usul Robo-robo}

Data 11

"disambot dengan suke cite oleh masyarakat Mempawah kale itu sehingge membuat Empu Daeng Menambon dan istrinye merase sangat senang" (Anonim)

Terjemahan:

"disambut dengan suka cita oleh masyarakat Mempawah waktu itu sehingga membuat Opu Daeng Menambon sangat senang".

Dari kutipan tersebut, nilai budaya kebahagiaan terlihat dalam kutipan tersebut yang menyatakan bahwa kedatangan Opu Daeng dan Istrinya disambut dengan suka cita hal itu membuat Opu Daeng Sangat senang.

7. Menghargai Kesehatan

Menghargai kesehatan merupakan sikap menjaga kesehatan diri pribadi, kesehatan masyarakat, dan kesehatan lingkungan (Samani dan Hariyanto, 129:2017). Nilai budaya kebahagiaan dalam cerita rakyat masyarakat Melayu Kabupaten Mempawah ditemukan dalam cerita rakyat Dara Hitam. Nilai budaya tersebut ditunjukan melalui data sebagai berikut.

\section{Cerita Rakyat 3 Dara Hitam}

Data 12

"pandai mengobati" (Anonim)

Terjemahan:

"pandai mengobati".

Dari kutipan tersebut, nilai budaya menghargai kesehatan terlihat dalam kutipan tersebut yang menyatakan bahwa Dara Hitam ini pandai atau bisa mengobati sehingga dengan keahlianya ini Dara Hitam pastinya juga memiliki sikap suka mengobati orang lain dia berperat sebagai dokter pada masanya.

\section{Keingintahuan Penasaran}

Keingintahuan penasaran adalah keinginan untuk menyelidiki dan mencari pemahaman terhadap rahasia alam atau peristiwa sosial yang sedang terjadi (Samani dan Hariyanto, 119:2017). Nilai budaya keingintahuan penasaran dalam cerita rakyat masyarakat Melayu Kabupaten Mempawah ditemukan dalam cerita rakyat Dara Hitam. Nilai budaya tersebut ditunjukan melalui data sebagai berikut.

\section{Cerita Rakyat 3 Dara Hitam Data 13}

"Mendengar hal itu Rajepon merase penasaran dan die memutoskan untok menyusorek sungai untok mencarik siape pemilik rambut itu." (Anonim)

Terjemahan:

"Mendengar hal itu Rajapun merasa penasaran dan dia memutuskan untuk menyusuri sungai untuk mencari siapa pemilik rambut itu". 
Dari kutipan tersebut, nilai budaya keinginahuan penasaran tergambar dalam kutipan tersebut pada saat Raja pensaran dengan rambut Dara Hitam dan ingin mengetahui siapa pemilik rambut itu.

\section{Kecerdasan}

Kecerdasan adalah sikap melakukan sesuatu dengan bijak hal-hal yang oleh orang lain mingkin tidak pernah dipikirkan atau diabaikan, mampu keluar secara cerdas suatu situasi sulit (Samani dan Hariyanto, 128:2017). Nilai budaya kecerdasan dalam cerita rakyat masyarakat Melayu Kabupaten Mempawah ditemukan dalam cerita rakyat Dara Hitam. Nilai budaya tersebut ditunjukan melalui data sebagai berikut.

\section{Cerita Rakyat 3 Dara Hitam}

Data 14

"Dengan kecerdasan Ria Sinir diapun dapat ngambek tengkorak kepalak Patih Gumantar tampe melakukan perang" (Anonim)

Terjemahan:

"Dengan kecerdasan Ria Sinir diapun dapat mengamil tengkorak kepala Patih Gumantar tampa melakukan perang".

Dari kutipan tersebut, nilai budaya kecerdasan terlihat dari kemampuan Ria Sinir yang dapat menyelesaikan masalahnya tampa melakukan perang.

\section{Kewaspadaan}

Kewaspadaan adalah menyadari apa yang sedang terjadi di sekeliling dan meresponsnya secara tepat dan benar (Samani dan Hariyanto, 116:2017). Nilai budaya kewaspadaan dalam cerita rakyat masyarakat Melayu Kabupaten Mempawah ditemukan dalam cerita rakyat Selusin Meriam Kuno. Nilai budaya tersebut ditunjukan melalui data sebagai berikut.

\section{Cerita Rakyat 9 Selusin Meriam Kuno}

Data 15

"Pade saat itu tu belande khawatir be seandainye meriam-meriam ni yang banyak tu akan menjadi alat bagi rakyat untok melawan pihaknye" (Anonim)

Terjemahan:

"Pada saat itu Belanda Khawatir seandainya meriam-meriam yang banyak itu akan menjadi alat bagi rakyat untuk melawan pihaknya".

Dari kutipan tersebut, nilai budaya kewaspadaan terlihat dalam kutipan yang menyatakan bahwa Belanda sangat waspada terhadap keberadaan meriam-meriam yang ada pada masa itu.

\section{E. Implementasikan dalam Pembelajaran Bahasa Indonesia}

Hasil penelitian ini diimplementasikan dalam pembelajaran Bahasa Indonesia yang terdapat dalam Kompetensi Dasar (KD) 3.7 Mengindentifikasi nilai-nilai dan isi yang terkandung dalam cerita rakyat (hikayat) baik lisan maupun tulisan. KD 4.7 Menceritakan kembali isi cerita rakyat (hikayat) yang didengar dan dibaca. Penelitian ini dpat diimplementasikan pada kurikulum 2013 pada kelas X (Sepuluh) semester ganji. Berdasarkan Kompetensi Dasar di atas, siswa di minta untuk menelaah dan menceritakan kembali cerita rakyat tersebut, sebelum menceritakan kembali cerita rakyat tersebut, siswa terlebih dahulu menterjemahkan kedalam bahasa Indonesia. Setelah selesai menterjemahkannya, maka siswa diperbolehkan untuk menceritakan kembali cerita rakyat tersebut berdasarkan struktur dan mengidentifikasi isi dari cerita rakyat tersebut.

\section{KESIMPULAN}

Berdasarkan hasil penelitian yang telah dilakukan dapat disimpulkan nilai budaya dalam cerita rakyat masyarakat Melayu Kabupaten Mempawah memiliki sembilan cerita rakyat yang 
didapatkan memalui dua informan dan 45 data dalam bentuk kata dan kalimat yang berkaitan dengan nilai budaya yang terbagi dalam empat nilai budaya sebagai berikut.

1. Nilai budaya dalam hubungan manusia dengan Tuhan terdapat 8 data yang berkitan dengan sikap berserah diri, sikap meminta perlindungan dan pertolongan kepada Tuhan, sikap mempercayai kebaikan dan keburukan berasal dari Tuhan, sikap mempercayai adanya hukuman dari Tuhan dan sikap saleh.

2. Nilai budaya dalam hubungan manusia dengan alam terdapat 6 data yang berkaitan dengan sikap percaya adanya mahluk gaib, dan sikap saling menghormati dan saling menjaga antar sesama mahluk hudup.

3. Nilai budaya dalam hubungan manusia dengan masyarakat terdapat 16 data yang berkaitan dengan sikap tidak mengambil milik orang lain, menghormati penyandang kekuasaan, suka membantu, penuh kasih sayang, ketangguhan, perhatian, cinta suka, kesetiaan, kebijaksanaan, kejujuran, suka kerja sama gotong royong.

4. Nilai budaya dalam hubungan manusia dengan diri sendiri terdapat 15 data yang berkaitan dengan sikap kerja keras, sikap sabar, tanggung jawab, sikap menjaga kebaikan diri, kebahagiaan, menghargai kesehatan, keingintaahuan penasaran, kecerdasan, dan kewaspadaan.

5. Hasil penelitian dapat diimplementasikan pada rencana pelaksanaan pembelajaran bahasa Indonesia kelas X, sı Mengidentifikasi nilai-nilai 130 ganjil, kurikulum 2013 pada Kompetensi Dasar 3.7 yang terkandung dalam cerita rakyat (hikayat) baik lisan maupun tulis.; Kompetensi Dasar 4.7 Menceritakan kembali isi cerita rakyat (hikayat) yang di dengae dan dibaca. Pada indikator pembelajaran mengidentifikasi nilai-nilai budaya pada cerita rakyat. Bahan ajar yang digunakan berupa naskah. Penyampaian bahan ajar dilakukan secara tidak langsung, menyesuaikan tingkat pemahaman peserta didik. Pembelajaran dengan menggunkan metode Inquiry dengan model pembelajaran berkelompok media yang di gunakan merupakan media berbasis cetak atau buku, sistem penilaian melalui tes yang diberikan berdasarkan materi pembelajaran yang di sampaikan.

\section{Saran}

Berdasarkan hasil penelitian, peneliti memberikan saran adalah sebagai berikut:

1. Para peneliti lain dapat menggembangkan hasil penelitian nilai budaya dalam cerita rakyat masyarakat melayu Kabupaten Mempawah dari aspek yang berbeda.

2. Para pembaca dapat menerapkan hasil penelitian ini sebagai bahal in dalam pengembangan nilai budaya dalam masyarakat maupun di sekolah.

3. Generasi muda dapat memperkenalkan kembali cerita-cerita lama, sebagai upaya pelestarian kearifan lokal.

4. Hasil penelitian nilai budaya dalam cerita rakyat masyarakat melayu Kabupaten Mempawah dapat di jadikan sebagai bahan acuan dalam pembuatan karya ilamiah.

\section{DAFTAR PUSTAKA.}

Emzir dan Saiful Rohman. 2016.Teori dan Pengajaran Sastra. Jakarta: Rajawalipers.

Endraswara, Suwardi. 2008. Metodelogi Penelitian Sastra. Yogyakarta: MediaPressindo.

Moleong, Lexy J.2017.Metodologi Penelitian Kualitatif. Bandung: RemajaRosdakarya.

Samani, Muchlas dan Harianti. 2017. Pendidikan Karakter. Bandung:PT Remaja Rosdakarya.

Sutono. 2017. Nilai budaya dalam mantra bercocok tanam padi di desa ronggo, kecamatan jaken, kabupaten jati, jawa tengah: kajian fungsi sastra.2(2), 25-45. 